\title{
P13 -Menores de edad inhumados en fosas clandestinas del conflicto armado: testimonios e indicios
}

\section{Minors buried in clandestine pits of the armed conflict: testimonies and signs}

\author{
Erwin Rolando Melgar Valenzuela*, María Teresa Mosquera \\ Centro de Análisis Forense y Ciencias Aplicadas, Guatemala* \\ ${ }^{2}$ Instituto de Estudios Interétnicos-USAC
}

\author{
*Autor para correspondencia. \\ Resumen \\ Correo electrónico: fer_bhppy@hotmail.com
}

$\mathrm{M}$

iles de menores de edad fallecieron en circunstancias asociadas con el conflicto armado interno en Guatemala. Los informes

de Guatemala Nunca Más y Guatemala Memoria del Silencio así lo evidencian. Sin embargo, en relación a menores y el conflicto armado, las investigaciones se han enfocado más hacia la niñez desaparecida. Las muertes de menores de edad, en este periodo, han quedado desdibujadas, al ser asimilados con la población adulta.Muchas de estas víctimas fueron inhumadas en fosas clandestinas diseminadas en las áreas del territorio nacional, en donde la violencia se manifestó con mayor intensidad. Las tareas de búsqueda, recuperación, análisis e identificación de cadáveres, en esas fosas, son realizadas por medio de pericias de antropología forense. Con el propósito de indagar los contextos vinculados con los fallecimientos de menores de edad, inhumados en fosas clandestinas, se recopilaron y procesaron datos registrados en archivos relacionados con peritajes de antropología forense. Pericias asociadas a 86 sitios, en donde se suponía fueron inhumadas víctimas del conflicto armado, entre las cuales se encontraban menores de edad. Según información testimonial, las personas enterradas en estos sitios fallecieron entre los años 1978 a 1993 , en circunstancias relacionadas con el conflicto armado. Los porcentajes elevados de menores de edad referidos en los testimonios y la cantidad individuos sub adultos localizados, evidencian el impacto que este periodo violento tuvo en la niñez guatemalteca.

Palabras clave: niños, conflicto armado, antropología forense, fosas clandestinas, violencia

\begin{abstract}
$\mathrm{I}$ Thousands of minors died in circumstances associated with the Internal Armed Conflict in Guatemala. The reports Guatemala Never Again and Guatemala Memoria del Silencio are evidence of this. However, in relation to minors and armed conflict, investigations have focused more on missing children. The deaths of minors, in this period, have been blurred, to be assimilated with the adult population. Many of these victims were buried in clandestine graves scattered in the areas of the national territory, where the violence manifested itself with greater intensity. The tasks of search, recovery, analysis and identification of corpses, in these pits, are carried out through forensic anthropology skills. With the purpose of investigating the contexts related to the deaths of minors, buried in clandestine graves, data recorded in files related to forensic anthropology surveys were compiled and processed. Experts associated with 86 sites, where they were supposed to be buried victims of the armed conflict, among whom were minors. According to testimonial information, the people buried in these sites died between 1978 and 1993, in circumstances related to the armed conflict. The high percentages of minors referred to in the testimonies and the number of sub adults located, show the impact that this violent period had on Guatemalan children.
\end{abstract}

Keywords: children, armed conflict, forensic anthropology, clandestine graves, violence 


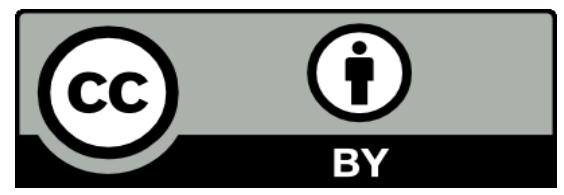

Este texto está protegido por una licencia CreativeCommons 4.0.

Usted es libre para compartir, copiar y redistribuir el material en cualquier medio o formato y adaptar el documento, remezclar, transformar y crear a partir del material para cualquier propósito, incluso comercialmente, siempre que cumpla la condición de atribución: usted debe reconocer el crédito de una obra de manera adecuada, proporcionar un enlace a la licencia, e indicar si se han realizado cambios. Puede hacerlo en cualquier forma razonable, pero no de forma tal que sugiera que tiene el apoyo del licenciante o lo recibe por el uso que hace. 